\title{
ГЕОПОЛИТИЧКИ ИНТЕРЕСИ ВЕЛИКИХ СИЛА НА БАЛКАНУ У ПОСЛЕДЊОЈ ДЕЦЕНИЈИ И КОСОВСКО ПИТАЊЕ
}

\author{
проф. др Жарко Обрадовић ${ }^{1}$
}

\begin{abstract}
Апстракт
Рад ће покушати да пружи одговор на питање зашто је Балкани у другој деценији XXI века поново постао предмет интереса великих сила и какав је био њихов међусобни однос у погледу балканских држава. На Балкану, поред већ раније присутних европских држава (чија је политика у савремено доба све више исказана кроз деловање Европске уније), Руске Федерације и Сједињених Америчких Држава, током ове деценије увећано је и присуство НР Кине (реализацијом бројних заједничких пројеката у области инфраструктуре, енергетике и др). Косовско питање, за које су западне земље тврдиле да је завршено, активношћу Србије је поново „отворено“ и постало је централни изазов целог региона, који, на свој начин, покушавају да реше Европска унија и САД. Споразум из Вашингтона је показао да САД предност дају економским питањима, уместо политичким, уз очекивање да ће такав приступ створити услове и за политички договор Београда и Приштине. Европска унија, са своје стране, именовањем специјалног изасланика за преговоре Београда и Приштине, настоји да кроз преговоре дође до закључења споразума о нормализацији односа сучељених страна. У исто време и ЕУ и САД, свако на свој начин, настоје да постигну још један циљ: да умање утицај и присуство НР Кине и Русије међу балканским државама.
\end{abstract}

Кључне речи: балканске државе, велике силе, Европска унија, косовско питање, геополитички интереси

1Проф. др Жарко Обрадовић, ванредни професор, Универзитет у Београду, Факултет безбедности. Е-пошта: obradovic.zarko60@gmail.com 


\section{УВОД}

Разбијање и нестанак социјалистичке Југославије, формирање шест нових држава, грађански рат и оружани сукоби, војна агресија НАТО на СР Југославију, стављање Косова и Метохије, јужне српске покрајине, под цивилну и војну управу Уједињених нација и други догађаји на простору бивше Југославије, пред крај прошлог и почетком XXI века, поново су у први план међународне сцене вратили Балкан као простор познат по свађама, сукобима, поделама, али и упливу великих сила. Не само да је Балкан стварањем нових држава, уз већ постојеће, добио нову територијално-политичку организацију, него су се на велика врата на полуострво вратиле и велике силе. По ко зна који пут у историји Балкана се показало да је тешко, готово немогуће, да се међу балканским народима нешто деси, а поготову реши, без активног учешћа неке од великих сила.

У последње три деценије интересовање за дешавања на Балкану највише је било присутно код западних земаља - Сједињених Америчких Држава и њених европских партнера, првенствено Немачке, а потом и Велике Британије, Француске и других. Ове државе су уједно највише утицале приликом доношења одлука од значаја за балканске народе. Руска Федерација такође је била присутна на Балкану. Она је била део већине договора и споразума, али је због унутрашњих политичких и економских проблема у којима се налазила током деведесетих година, што се последично одражавало и на војну снагу државе, често била принуђена да се сагласи са одлукама САД и њених сарадника, без озбиљније моћи да на њих утиче, односно да их промени. Доласком В. Путина на чело Руске Федерације ситуација се потпуно променила, како унутар земље, тако и на међународном плану. Руска Федерација је поново постала глобална сила, војна и политичка, а самим тим и поново важан фактор дешавања на простору Балкана. У последњој деценији још једна глобална сила, Народна Република Кина, исказала је своју заинтересованост за простор Балкана, и то најпре преко економске и политичке сарадње са балканским државама. Потврда томе је сарадња у оквиру Процеса 17+1 (сарадња Кине са земљама централне и Источне Европе), као и нарочито бројни заједнички пројекти Кине са Србијом, који су ову сарадњу и представили као најјачи доказ присуства интереса Кине на простору Балкана.

У погледу оријентације, тј. припадништва балканских држава различитим европским и трансатлантским политичким и војним интеграционим организацијама, потребно је констатовати да су, са изузетком Србије и БиХ, остале државе Балкана опредељене за чланство у Европској унији и/или Организацији северноатлантског споразума (НАТО). Од 11 балканских држава њих пет су чланице Европске уније (Грчка, Словенија, Бугарска, Румунија и Хрватска), пет држава имају статус кандидата за чланство (Албанија, Турска, Северна Македонија, Црна Гора и Србија), док је Босна и Херцеговина још увек у статусу потенцијалног кандидата за члана ЕУ. У погледу чланства у НАТО пакту, девет балканских држава су чланице НАТО-а (Грчка, Турска, Албанија, Бугарска, Румунија, Словенија, Хрватска, Црна Гора и Северна Македонија). Србија је прогласила војну неутралност, а сарадња са НАТО-ом се одвија у оквиру програма Партнерство за мир. У Босни и Херцеговини постоје различити ставови два 
ентитета у погледу чланства БиХ у НАТО. Федерација БиХ је за чланство у НАТО пакту, а Република Српска је против. Државе на Балкану су доминантно опредељена за економску сарадњу са земљама Европске уније. Све то је простор Балкана претворило у зону интереса Европске уније и НАТО-а.

Сучељавање великих сила на Балкану, али и комплексност односа балканских држава и спољног фактора, у савремено доба највидљивије се исказује кроз решавање косовског питања и присуство НР Кине. Али косовско питање показује да појединачни интереси великих сила увек имају предност и да се користи свака прилика да би се стекао примат једне у односу на другу (САД у односу на ЕУ и обрнуто) или да би се истиснула трећа страна (Кина и Русија кроз економску помоћ балканским државама од стране ЕУ и САД). Поред овог, постоје и бројна друга, наизглед мање важна питања, кроз које (или преко којих) се може констатовати присуство и утицај једне или више великих сила.

\section{ЕУ, САД И КОСОВСКО ПИТАҢЕ}

Иако су западне земље, како Сједињене Америчке Државе, тако и државе чланице Европске уније и НАТО-а, јединствено деловале приликом агресије на СР Југославију и приликом признавања тзв. независности Косова, као и приликом доношења различитих врста одлука о подршци Косову у међународним организацијама, ипак се у њиховом односу према косовском питању могу приметити, не само различити приступи, већ и жеља да примарно утичу на Београд и Приштину.

Први преговори вођени су током 2006. и 2007. године под окриљем канцеларије специјалног представника генералног секретара УН за разговоре о будућем статуту Косова и нису дали резултате. Важно је констатовати да са преусмеравањем преговарачког процеса са глобалног нивоа у оквиру Уједињених нација на ниво Европске уније променио и однос заинтересованих страна унутар западних земаља према садржају и судбини косовског питања. Уместо Сједињених Америчких Држава, које су биле главне у доношењу свих одлука у вези са Косовом и Метохијом (не само у Уједињеним нацијама, него и другим мултилатералним организацијама, приликом признања тзв. независности Косова и њеној промоцији међу другим државама), главну улогу у преговарачком процесу и решавању косовског питања преузела је Европска унија.

„Бригу“ о косовском питању од Сједињених Америчких Држава преузела је Европска унија 2010. године. Наиме, после доношења Саветодавног мишљења Међународног суда правде у Хагу, 22. јула 2010. године, о томе да ли је једнострано проглашење независности Косова у складу са међународним правом², које је било вишезначно и објективно негативно по Србију, Генерална

2 Генерална скупштина Уједињених нација је 08. октобра 2008. године, на предлог Србије, усвојила Резолуцију којом се од Међународног суда правде у Хагу тражи Саветодавно мишљење о питању да ли је Декларација о независности, која је једнострано усвојена од 
скупштина УН, на основу мишљења Суда, остала је место које има „широка овлашћења да расправља о овом питању“. Нешто више од два месеца касније, 9. септембра 2010. године, Генерална скупштина усвојила је резолуцију коју је направила Србија заједно са неким западним земаљама, у којој се обе стране (представници Републике Србије и представници привремених институција самоуправе у Приштини) позивају „на дијалог под окриљем Европске уније, који би имао за циљ да унапреди сарадњу и оствари напредак ка ЕУ и побољша живот грађана“"3. Од 2011. године, када су одржани први преговори између Београда и Приштине уз посредовање Европске уније ${ }^{4}$, одржано је више десетина састанака, у којим су учествовали представници Београда и Приштине. Током преговора су потписани бројни споразуми, од којих је најпознатији Бриселски споразум, потписан 19. априла 2013. године. За разлику од Београда, који је испунио скоро све обавезе из потписаних споразума, косовски Албанци нису спровели до краја ниједан од 48 потписаних споразума5, укључујући и одредбе Бриселског споразума о формирању Заједнице општина у којима Срби чине већинско становништво. 6

Због одлуке Приштине да уведе таксу од 100 процената на робу из Србије, новембра 2018. године дошло је до прекида преговора између Београда и Приштине, који је трајао 20 месеци. Преговори су поново настављени јула 2020. године. У међувремену, Србија је покренула активности према државама које су

привремених органа локалне самоуправе на Косову 17. фебруара 2008. године, у сагласности са међународним правом. У саветодавном мишљењу Међународног суда правде констатовано је да опште међународно право не садржи ниједну важећу забрану проглашења независности, и у складу с тим, Декларација о независности није прекршила опште право. Суд је такође констатовао да ни Резолуција 1244 Савета безбедности, нити уставни оквир, не садрже клаузулу о њиховом престанку важења и да ни једно ни друго није стављено ван снаге и стога су они чинили међународно право применљиво на ситуацију која је постојала на Косову и Метохији фебруара 2008. године. Суд је, између осталог, нагласио да на Косову наставља да функционише међународни правни режим успостављен Резолуцијом 1244 и није потврдио право Косова на отцепљење од Републике Србије. Наведено према: Извештај о саветодавном мишљењу Међународног суда правде, Министарство спољних послова Владе Републике Србије, Београд 23. јул 2010. године; У: Обрадовић В. Жарко, Балкански етнички мозаик мањинско питање на Балкану, Чигоја штампа, Београд 2014, стр. 612-614.

3 Наведено према: Обрадовић В. Жарко, нав. дело, стр. 614.

4 У име Европске уније, посредници у преговорима били су Кетрин Ештон и Федерика Могерини, високе представнице Европске уније за спољну политику и безбедност. Почетком априла ове године Савет Европске уније именовао је Мирослава Лајчака за специјалног представника ЕУ за дијалог Београда и Приштине и друга регионална питања Западног Балкана.

5 Наведено према: „Економска нормализација без статусних питања - Да ли ће Албанци овога пута поштовати потпис“, Политика, субота 5. септембар 2020, стр. 6.

6 Видети детаљније: „Асоцијација/заједница општина са већинским српским становништвом на Косову - општи принципи/главни елементи“, Канцеларија за Косово и Метохију Владе Републике Србије, Документа: Преговарачки процес са Приштином, http://www.kim-gov.rs/pregovaracki-proces.php, Приступљено 10.10.2020. 
признале тзв. независно Косово са циљем да оне своју одлуку промене, промовишући становиште да је неопходно да дијалог има предност над једностраним решењима. Аргументи Србије наишли су на разумевање код 18 држава које су повукле или суспендовале одлуке о признавању Косова као независне државе 7 . Смањење броја држава које су признале тзв. државу Косово имало је две практичне последице. Прва се исказала у томе да Косово у Уједињеним нацијама није више имало већинску подршку држава чланица ${ }^{8}$. Друга последица повлачења признања или „отпризнавања“9 Косова огледала се у немогућности Косова да у различитим међународним организацијама обезбеди довољан број гласова за пријем у чланство. Зато Косово није постало члан УНЕСКО-а, Интерпола и др. мултилатералних организација. На општем плану, повлачење признања Косова је показало да Србија име бројне пријатеље у свету (укључујући и велике силе, Русију и Кину), да косовско питање није завршено, како су сматрале западне земље, и да се без Србије не може наћи трајно и праведно решење косовског питања.

Реагујући на овакву ситуацију (прекид преговора између Београда и Приштине, повлачење признавања независности Косова од стране 18 држава) и са намером да се активно укључе у преговарачки процес и наметну своја решења, и САД и ЕУ су именовале посебне представнике за дијалог Београда и Приштине. Председник САД Доналд Трамп је почетком октобра 2019. године именовао дипломату Ричарда Гренела за специјалног изасланика за дијалог Београда и Приштине, док је Европска унија крајем марта 2020. године за свог специјалног представника именовала Мирослава Лајчака, такође дипломату.

Именовање специјалног представника ЕУ за дијалог Београда и Приштине, показује јасну намеру Европске уније да се прекинути разговори обнове под окриљем ЕУ, да је ЕУ главни актер у решавању косовског питања (jер је то „европски проблем“) и да ЕУ треба да има предност у односу на Сједињене Америчке Државе по овом питању. То потврђује и најновија изјава комесара ЕУ за

7 Државе које су повукле или суспендовале признање Косова су: Сијера Леоне, Република Науру, Гана, Того, Централноафричка Република, Република Палау, Мадагаскар, Соломонска Острва, Лесото, Суринам, Гранада, Унија Комора, Бурунди, Комонвелт Доминика, Сао Томе и Принсипе, Либерија, Гвинеја Бисао и Папуа Нова Гвинеја. Наведено према: Dačić: Sijera Leone 18. država koja je povukla priznanje Kosova; Priština nema informacija o povlačenju; 3. mart 2020. god. https://kossev.info/dacic-sijera-leone-.je18-drzava-koja-je-povukla-priznanje-kosova/ Приступљено, 15.3.2020. год.

8 Према подацима Србије „тренутно од 193 чланице УН, 92 земље признају независно Косово, 96 земаља не признају Косово, док се 5 земаља налази у флуидном стању, односно углавном признају Косово, али више не гласају за Косово“ Dačić: Sijera Leone povukla priznanje Kosova“, 3. mart 2020, https://www.rts.rs/page/stories/sr/story/9/politika/3873986/kosovo-priznanje-siera-leone.html,

Приступљено 15.3.2020. год.

9 Видети детаљније: „Dačić: Srbija je u međunarodno pravo uvela izraz otpriznavanje“, 7. jun 2020, https://www.kosovo-online-com/vesti/politika/dacic-srbija-je-u-medjunarodno-pravouvela-izraz-otpriznavanje-7-6-2020, Приступљено, 10.9.2020. 
спољну и безбедносну политику, дата у оквиру Самита министара спољних послова земаља чланица ЕУ, одржаног 12.10.2020. године у Луксембургу, који тврди да је намера ЕУ да „приведе дијалог Београда и Приштине успешном завршетку“, да је успех дијалога „кључан за стабилност западног Балкана и целе ЕУ“, као и да постоји „само један дијалог, и то онај који води ЕУ“.10 На истом састанку, специјални представник за дијалог Београда и Приштине истакао је још једну важну димензију косовског питања која одражава и став Европске уније, а то је да постоји „јасна веза између дијалога и европске будућности Србије и Косова“. 11

Остаје без одговора питање зашто Европска унија није до сада озбиљније реаговала на понашање привремених институција на Косову, које су после потписивања Бриселског споразума опструирале његово усвајање у тзв. Парламенту Косова, и нису желеле да примене одредбе о формирању Заједнице српских општина, као и бројне друге потписане споразуме. ${ }^{12}$ Косово је поред тога доносило једностране одлуке (о увођењу такси на робу из Србије и Босне и Херцеговине, о формирању своје војске и др.) које су одлагале разговоре и постизање (било каквог) договора. Представници привремених институција на Косову и сада имају истоветан став око одредаба за ЗСО као и у протеклим годинама: да оне неће бити примењене у облику у ком су потписане у Бриселу 2013. године. Премијер привремених институција А. Хоти је потврдио „да на Косову и Метохији неће бити формирана Заједница српских општина са извршним моћима, већ онако како Уставни суд Косова налаже“. Поред тога Хоти је истакао „да се ништа неће применити док се не закључи коначни споразум о узајамном признању и док не буде ратификован у Скупштини“.13 Очигледно је да

10 Наведено према: „Стара понуда у новом паковању - Борељ: Финални договор могућ за неколико месеци“, Политика, 13.10.2020., стр. 6.

11 Наведено према: „Lajčak: Jasna veza dijaloga i budućnosti Srbije i Kosova u EU“, 12.10.2020, https://www.rtv.rs/sr-lat/evropa/sefovi-diplomatije-eu-u-luksemburgu-o-dijalogubeograda-i-pristine-11691142.html

Приступљено 13.10.2020

12 После усвајања Бриселског споразума привремене институције на Косову су вршиле различите врсте опструкције како споразум не би био усвојен и примењен. Посланици покрета Самоопредељење су више пута бацали сузавац у просторије скупштине, чиме није било могуће одржавање седнице. Осим тога, Бриселски споразум је био и предмет анализе косовског Уставног суда, који је „утврдио“ да бројне одредбе споразума нису сагласне Уставу тзв. Косова и поништене су. Касније су измислили „да је документ писан ћирилицом“ и да зато не желе да анализирају нацрт статута. Поред свега наведеног, бројне седнице нису одржане јер наводно није било могуће обезбедити кворум у Парламенту. Последњи пример опструкције је да споразум не треба применити док се у „Прешевској долини“ не формира заједница албанских општина, иако је само Прешево град где Албанци чине већину. Наведено према: „Куртијев сузавац, летњи одмор и „Прешевска долина“ као изговори“, Политика, понедељак 12.10.2020., стр. 6.

13 Наведено према: „Хоти: Неће бити ЗСО са извршним моћима“, Политика, среда 14.10.2020, стр. 6 . 
водећи представници косовских Албанаца не желе да формирају 3СО и да другачије мишљење не прихватају. ${ }^{14}$ Нажалост, јасно је да ни ЕУ, бар до сада, не жели да изврши било какав озбиљнији притисак на Приштину да испуни своје обавезе. Чини се да и једни и други чекају да Србија призна независно Косово и тиме обесмисли Бриселски и друге споразуме које Приштини није испунила. Став Србије је саопштио њен председник после састанка са представником Европске уније - да дијалог треба наставити, да Србија жели „да се дође до компромисног решења у циљу стварања бољих односа између Срба и Албанаца и нормализације односа кроз одлуке УН и ЕУ, Београда и Приштине“.15 Уз ове речи, председник Србије је истакао да Србија инсистира на пуној имплементацији Бриселског споразума из 2013. године (укључујући и формирање 3С0) и да је то „услов без ког не може бити успешно настављен дијалог“.16 И представници Српске листе, која учествује у раду привремених институција на Косову, затражили су имплементацију споразума из Брисела, уз претњу да ће у супротном „бити размотрена могућност напуштања свих централних институција у Приштини и укидање свих приштинских институција у већинским српским срединама на КиМ“.17 Специјални представник ЕУ је после посете Приштини и Београду изјавио да „све што је договорено у Бриселу мора да се испуни“,18 и да је циљ ЕУ

14 Косовски писац и публициста Ветон Сурои не дели ставове водећих људи привремених институција на Косову око обавезе примене Бриселског споразума. По његовом мишљењу чињенично стање око Бриселског споразума и Заједнице српских општина се показује кроз четири тачке:

1) Премијер Косова Хашим Тачи је потписао 2013. год. споразум о оснивању ЗСО, који предвиђа трећи ниво власти;

2) Косово је тада прихватило обавезу да „треба да промени свој правни оквир како би у њега укључио Заједницу српских општина“;

3) Скупштина Косова је ратификовала, са двотрећинском већином посланика, овај споразум. Тиме је потврђена обавеза „успостављање Заједнице српских општина као трећег нивоа власти, између централног и локалног“;

4) Премијер Косова 2015. године потписао је споразум који је „наставак споразума из 2013. год., који описује принципе територијалне аутономије Срба на Косову".

Наведено према: „Kosovo: Oštre reakcije na izjavu Lajčaka da Ustav nije Biblija“, 17.10.2020. https://www.danas.rs/politika/ostre-reakcije-na-kosovu-na-izjavu-lajcakada-ustav-nije-biblija-i-da-je-moze-menjati

Приступљено 19.10.2020

15 Наведено према „Вучић: Инсистирао сам на пуној примени Бриселског споразума; Лајчак: Договорено мора бити испуњено“, Четвртак, 15. октобар 2020. https://www.rts.rs/page/stories/ci/story/1/politika/4114507/vucic-lajcak-sastanakbeograd-priština.html

Приступљено 19.10.2020

16 Исто.

17 Наведено према: „Може ли Лајчак да изврши притисак на Албанце“, Политика, среда 14.10.2020, стр. 6.

18 Наведено према: „Вучић: Инсистирао сам на пуној примени Бриселског споразума; Лајчак: Договорено мора бити испуњено“, Исто. 
„нормализација односа“, о којој треба да се „договоре две стране“. Оно што Лајчак није рекао је кад и како ће договорено у Бриселу бити испуњено и шта ће Европска унија учинити са своје стране да Приштина испуни своје обавезе.

Европска унија већ неколико година најављује финансијску подршку Западном Балкану, како би овај простор што више „везала“ за себе и уједно умањила присуство и утицај Кине међу балканским државама. Пандемија вируса Ковид 19 одложила је представљање тог финансијског плана током маја ове године. Ипак, чини се да је споразум из Вашингтона, потписан 4. септембра 2020, и иницијатива САД за економским јачањем присуства у региону Балкана убрзала активности Европске комисије у правцу представљања инвестиционог плана за Западни Балкан, што је и учињено почетком октобра. План предвиђа улагање девет милијарди евра бесповратне помоћи за реализацију бројних пројеката. Средства су предвиђена за „саобраћајнице, енергетику, заштиту животне средине, мала и средња предузећа и дигитализацију, а посебан програм је намењен младима“19. У свакој од ових области предвиђена је реализација бројних пројеката који ће не само међусобно повезати простор Западног Балкана и са суседним државама, већ и значајно унапредити економски развој региона и квалитет живота грађана. Међу бројним пројектима треба поменути модернизацију југоисточног крака на Коридору 10 (од Мађарске, Западног Балкана, до Бугарске, Грчке и даље), обнова железничке пруге Београд - Подгорица - Бар, завршетак аутопута од Хрватске до Грчке, завршетак Трансбалканског коридора за пренос енергије у Србију, као део интерконекције између Србије, Црне Горе и БиХ; улагање у заштиту животне средине у Србији, успостављање интегрисаних регионалних система управљања отпадом у Албанији, Србији, Црној Гори и Северној Македонији, подршка дигиталном сектору и др. ${ }^{20}$ Поред бесповратне помоћи од 9 милијарди евра, ЕУ намерава да у наредној деценији инвестира на Западном Балкану још 20 милијарди евра. Циљ који ЕУ жели да постигне је да „дугорочно буде ангажована на Западном Балкану“ и да је „инвестициони план за регион део нове стратегије према региону и Србији“.21 Да инвестициони план за Западни Балкан има и стратешку димензију, јачу интеграцију простора Западног Балкана у европске интеграционе процесе, као и сузбијање присуства и утицаја Кине, потврдила је председница Европске комисије Урсула Фон дер Лајер констатацијом да је „Западни Балкан део Европе“, а не станица на „Путу свиле“22. Када је о присуству

${ }^{19}$ Наведено према: Šta će sve EU finansirati na Zapadnom Balkanu, 6. oktobar 2020, https://www. Slobodnaevropa.org/a/\%C5\%A1ta-\%C4\%87-e-sve-eu-finansirati-nazapadnom-balkanu/30878793.html

Приступљено 10.10.2020.

20 Видети детаљније: Исто

${ }^{21}$ Наведено према: Комесар за проширење ЕУ Оливер Вархељи у Београду: Европски порески обвезници уложиће у Србију огроман новац, Политика, петак, 9. октобар 2020. стр. 5.

22 Наведено према: Председница ЕК: Западни Балкан је део Европе, а не станица на „Путу свиле“, Политика, петак 9. октобар 2020., стр. 5. 
Кине у Србији реч и о планираним и реализованим кинеским инвестицијама, комесар за проширење ЕУ истакао је „да ЕУ има бољу понуду“ (од Кине - прим. аут.) ${ }^{23}$.

Ограничавајући аспект овог инвестиционог плана огледа се у чињеници да прва средства за реализацију пројеката земље Западног Балкана могу да очекују, према „скромној процени“ комесара за проширење ЕУ24, тек 2024. године, а остала средства и касније. Поред тога, планирано је да доступност средстава буде „повезана са оствареним степеном напретка државе кандидата у испуњавању услова чланства у ЕУ по принципу „више за више“,25 што ће несумњиво бити предмет политичких оцена (и интереса) чланица ЕУ, што може успорити доступност средстава, а самим тим и реализацију пројеката на простору Западног Балкана.

Унутар Европске уније, Савезна Република Немачка има главну улогу у креирању ставова који се односе на косовско питање, како према Београду, тако и према Приштини, наравно, на различите начине. Наиме, Немачка је већ дуго веома активна у помоћи и подршци косовским Албанцима у стицању и промоцији тзв. независности. Ослободилачка војска Косова имала је подршку обавештајних служби Немачке (и САД) у снабдевању потребним оружјем и новцем. ${ }^{26}$ Немачка је била међу водећим западним земљама у ширењу лажних вести о дешавањима на Косову и Метохији или преувеличавању појединих догађаја, а тиме у стварању атмосфере „кршења права Албанаца на Косову“, „одговорности Србије“, као и у захтевима да се Србија због тога казни, односно бомбардује. ${ }^{27}$ Након завршетка бомбардовања, немачка војска је под окриљем НАТО-а, добила „зону своје одговорности“ (поред британске, америчке, француске и италијанске војне зоне). ${ }^{28}$ У пракси, то је значило ћутање и нереаговање, а тиме и амнестирање Албанаца за све злочине које су чинили против неалбанског становништва на Косову приликом масовног протеривања Срба са простора КиМ у другој половини 1999. године, као и касније, уклањањем трагова о злочинима које је починила ОВК на Косову, пре и током бомбардовања Србије 1999. године, о чему је писао и Дик Марти у свом Извештају о трговини људским органима, који је усвојио Савет Европе 2011. године. ${ }^{29}$ Са почетком преговарачког процеса Србије са Европском

23 Наведено према: Комесар за проширење ЕУ, Исто, стр. 5.

24 Исто, стр. 5.

25 Наведено према: Европски одговор на „Пут свиле“ и ДФЦ, Политика, субота 10. октобар 2020, стр. 6.

26 Наведено према: Кривокапић др Борис, Агресија НАТО-а на Југославију - сила изнад права, Чигоја штампа, Београд 1999., стр. 8.

27 Видети детаљније: Vujović Mišo, Masakriranje istine, Kulturni centar „Sveti Sava“ Podgorica, Beograd 2002. godine

${ }^{28}$ Наведено према: Strane trupe na Kosovu, https://www.vreme>com>arhiva.htm,443

3. jul 1999. god. Приступљено 24.8.2020.

${ }^{29}$ Видети: Резолуција парламентарне скупштине Савета Европе (RES 1782/2011), усвојена 25. јануара 2011. год. У: Косово и Метохија: 1920-2010, хронологија, Момчило Павловић и др.; Институт за савремену историју, Београд 2011, стр. 671-699; Обрадовић В. Ж., 
унијом о стицању статуса члана ЕУ, Немачка није пропуштала прилику да „отежа“ пут Србије, постављајући различите услове и ултиматуме према Србији, самостално или преко Европске уније. Тако је део ставова које је А. Меркел, председница владе СР Немачке, пренела највишим представницима Србије приликом посете 2011. године, нашао „своје место“ у одредбама Бриселског споразума из 2013. године. 30 Као што је и део захтева које је у име групе посланика немачког парламента, припадника владајуће Хришћанско-демократске уније, јавности Србије саопштио А. Шокенхоф приликом посета̂ Србији 2012. и 2013. године, нашао своје место у документима ЕУ, који чине преговарачки оквир Србије са ЕУ. Чак је један од тада саопштених седам немачких захтева, онај о закључењу обавезујућег споразума о нормализацији односа Београда и Приштине, постао садржај посебног поглавља 35 у преговорима о чланству Србије у Европску унију. ${ }^{31}$ Немачки утицај се огледа и у оснивању и раду иницијативе Берлински процес (од 2014. године), у којој учествују земље Западног Балкана (укључујући и тзв. Косово) и водеће земље Европске уније са циљем веће сарадње и развоја земаља Западног Балкана 32 . Постављање М. Лајчака на место специјалног представника ЕУ за дијалог између Београда и Приштине сигурно је имао „немачку димензију“ (прим. аут.), с обзиром на информације да је Немачка желела да има свог кандидата 33 , али још више због чињенице да избор

Балкански етнички мозаик - мањинско питање на Балкану, Чигоја штампа, Београд 2014. стр. 618-619.

30 Видети детаљније: Poseta Angele Merkel Beogradu: kad kancelarka gleda na sat, 25.08.2011, https://www.vreme.com>cms/view

Приступљено 26.08.2020; Vraćanje u 2012. - Plan Berlina i reči Olivera Ivanovića, https://www.b92, 15.08.2018.

Приступљено 19.8.2020. У Обрадовић Ж., Безбедносни изазови и стубови спољне политике Србије, Тематски зборник радова са међународне научне конференције: „Дани Арчибалда Рајса“, Криминалистичко-полицијска академија у Београду, Београд, стр. 219-233.

31 Услови немачких парламентараца које је представио Андреас Шокенхоф били су: спровођење дотадашњих споразума постигнутих у дијалогу са Приштином, наставак започетих реформи у области правосуђа и реализација Акционог плана, почетак укидања паралелних структура Србије (у безбедносном апарату и управи) на северу Косова, видљив напредак у разјашњењу паљења немачке амбасаде у демонстрацијама фебруара 2008. године, обавезујући споразум о успостављању добросуседских односа са Приштином, да Београд утиче на Србе на северу Косова да сарађују са ЕУЛЕКС-ом и КФОР-ом, побољшање односа са државама у региону, посебно са БиХ. Наведено према: „Šta Angelina stranka očekuje od nas“ B92. Net https://www.b92.net 13.09.2012, Приступљено 16.08.2018: „Vraćanje u 2012 - „plan Berlina“ i reči Olivera Ivanovića“, https://www.b92.net, 15.08.2018, Приступљено 19/08/2018, У: Исто, стр. 219-233.

32 Видети детаљније: Ђукановић Драган, Крстић Милан, Берлински процес - Немачка „Западнобалканска“ иницијатива, Српска политичка мисао, број 4/2016, год. 23. vol. 54, Београд 2016. године, стр. 169-185.

33 Видети детаљније: „Posrednika EU u dijalogu Kosova i Srbije odrediće Nemačka“ https://www.slobodnaevropa.org/a/posrednika-eu-u-dijalogu-kosova-i-srbijeodredice\%C4\%87e-nema-\%C4\%8DKa-\%30169891.html 
специјалног представника ЕУ није могао „проћи“ уколико кандидат нема ставове сличне или истоветне немачким ${ }^{34}$, водеће земље ЕУ.

У погледу односа према косовском питању постоји повезаност интереса Немачке и САД, и та „веза“ траје јако дуго, јер је тзв. косовска држава „чедо и америчко и немачко и свих оних који су стварали независно Косово“35. Суштина немачке и америчке политике према тзв. косовској независности се у општим питањима не разликује, само су њихови конкретни потези понекад различити.

Поред свих напред поменутих (једностраних) потеза Немачке у решавању косовског питања, треба додати и „ћутање“ Немачке на потезе косовске стране који су били директно уперени против дијалога Београда и Приштине или против примене потписаних докумената. Немачка је тако прилично тихо пропратила одлуку привремених институција из Приштине о увођењу такси на робу из Србије, иако је то било супротно потписаним ЦЕФТА споразумима. Код одлуке Приштине да формира своју војску, што је супротно Резолуцији 1244 Савета безбедности, Немачка је нашла речи оправдања за тај потез. У односу на могући договор између Београда и Приштине о „размени територија“, који се и код косовских и код српских преговарача тек овлаш помињао, Немачка је била једна од ретких великих земаља која се противила таквом решењу, јер је сматрала да су границе на Балкану коначне и непроменљиве и да свако такво решење може имати „домино ефекат“ у региону. Такав став Немачке представља пример двоструких аршина, јер је она, кад је о Косову реч, подршком ОВК и учешћем у НАТО бомбардовању Србије 1999. године, и касније, признавањем тзв. независности Косова, била директни актер промена граница Србије. Поред тога, логично би било да након свега што се у прошлости десило између Београда и Приштине, ако две стране, дојучерашњи велики непријатељи, могу у разговорима да дођу до једног трајног, обострано прихватљивог решења, ма какво оно било по свом садржају, па чак и да укључује територијалне промене, поставља се питање зашто би нека трећа земља (у овом случају Немачка) била против, осим ако нема своје посебне интересе. У случају Немачке реч је управо о томе. Имплементирајући своје ставове (и интересе) кроз документа и одлуке Европске уније, у односима са САД појединачно, а и на нивоу ЕУ, она све више наступа као самостални фактор. Ни остале земље чланице ЕУ до сада нису показале одлучност

34 Поводом именовања М. Лајчака за специјалног представника ЕУ, некадашњи дипломата 3. Миливојевић констатовао је да ће Лајчак „бити на линији онога што је званични став у Бриселу, који у овом тренутку на најдиректнији начин промовишу Берлин и Париз... и да ће бити близак, пре свега, ставу Немачке“. Наведено према: „Miroslav Lajčak imenovan za specijalnog predstavnika EU za dijalog", https://www.Rtv.rs/sr-let/politika/miroslavlajcak.imenovan-za-specijalnog-predstavnika-eu-za-dijalog.....1109956.html

Приступљено 12.10.2020.

35 Наведено према: „Kosovo je američko i nemačko čedo: Aleksandar Vučić otvoreno o kosovskom čvoru: Velike sile imaju svoj interes“, 07.06.2020., https://www.kurir.rs/vesti/politika/3477037/kosovo-je-američko-i-nemako-čedoaleksandar-vučić-otvoreno-o-kosovskom-cvoru-velike-sile-imaju Приступљено 08.06.2020. 
да натерају косовску страну да испуни своје обавезе, што суштински значи да Косово има њихову прећутну сагласност за своје „нечињење“.

Први састанак између делегација Београда и Приштине у организацији Р. Гренела, специјалног изасланика Доналда Трампа, требао је да се одржи крајем јуна 2020. у Вашингтону. Састанак је званично отказан због одбијања премијера Косова А. Хотија да дође у САД „због дешавања у вези с оптужницама које је поднело Специјално тужилаштво“36 против водећих људи косовских Албанаца, Х. Тачија и К. Весељија, због ратних злочина на Косову. Незванично, оцена је да подизање оптужнице представља покушај Немачке и „дубоке државе“ у Америци да спрече дијалог између Београда и Приштине у организацији САД, како би се продубиле разлике између Европске уније и САД око начина решавања косовског питања и спречила афирмација спољне политике Д. Трампа уочи америчких председничких избора. ${ }^{37}$ Ипак, састанак у Вашингтону је одржан 3. и 4. септембра 2020. године. Поред разговора делегација Београда и Приштине са Р. Гренелом, организован је и састанак две делегације са председником Сједињених Америчких Држава, као и потписивање споразума̂ о економској сарадњи. Београд (председник Србије А. Вучић) и Приштина (премијер тзв. Косова А. Хоти) су потписали само свој примерак документа, а председник САД Д. Трамп је ставио свој потпис на сваки примерак документа. ${ }^{38}$ Није потписан никакав документ између Београда и Приштине. Споразуми које су потписали представници Београда и Приштине садрже по шеснаест тачака, од којих се разликује само последња тачка, која се односи на Израел.

Садржај споразума показује да је Америка у потпуности дала предност економској димензији односа Београда и Приштине, као што је реализација инфраструктурних пројеката (изградња аутопута, железнице, економски развој и сарадња у региону) у односу на политичку, уз очекивања да ће се унапређењем економске ситуације створити услови и за политички договор. Споразум садржи и

${ }^{36}$ Наведено према: „Трамп на удару Брисела, Берлина и дубоке државе - зашто су се приштински преговарачи повукли са састанка у Вашингтону“, Политика, Петак 26. јун 2020 , стр. 5.

37 На умешаност Немачке у догађаје који су утицали на отказивање доласка приштинске делегације у САД „упућује недавна изјава једног од кључних актера немачке политичке сцене Питера Бајера, који је, како тврди, позвао представнике Београда и Приштине да не иду у Вашингтон и не прихватају никакав „прљави“ споразум Ричарда Гренела“. Наведено према: Исто, стр. 5.

38 у нацрту Споразума који је био предмет разговора српске делегације са Р. Гренелом, првог дана састанка, налазила се и тачка 10, која се односи на признавање Косова. Наиме, тачка 10 је гласила: „Обе стране се обавезују на међусобно признавање и заштиту етничких мањина, реституцију имовине, решавање статуса државних званичника, као и усаглашавање о отварању канцеларија задужених за заштиту мањинских група којима ће достављати годишње извештаје“. Након одбијања Председника Републике Србије А. Вучића да прихвати овај члан, он је уклоњен из коначног садржаја документа. Наведено према: Ултиматум у Белој кући: Ево како гласи кобна тачка 10, четвртак, 03.09.2020, Novosti online; Приступљено 4.10.2020. 
две одредбе које имају ширу димензију односа у региону (питања снабдевања енергијом и употребе 5Г опреме) и имају за циљ смањење присуства и утицаја других држава, пре свега Русије и Кине.

Одредбе које су регионалног карактера односи се пре свега на оснивање сталног представништва америчке Међународне корпорације за финансијски развој у Србији (Београду). Главни циљеви ове корпорације су операционализација саобраћајних пројеката: аутопута мира, који ће повезивати Ниш и Приштину, железничке везе између Приштине и Мердара и железничке везе између Ниша и Приштине. Задатак Корпорације је обезбеђивање финансија за подршку зајмовима потребним за мале и средње бизнисе, као и за додатне билатералне пројекте. Наравно, обавеза Београда и Приштине је да сарађују са корпорацијом на испуњењу постављених циљева. 39

Остале одредбе односиле су се на спровођење споразума̂ Београда и Приштине о аутопуту и железници који су потписани 14. фебруара ове године, изради заједничке студије о изводљивости којом би се нашле опције повезивања инфраструктуре железнице Београд - Приштина са луком на Јадрану, успостављање оперативним заједничког објекта на прелазу Мердаре, функционисање „Зоне мини шенгена“ коју су најавиле Србија, Албанија и Северна Македонија 2019. године, узајамно признавање диплома и професионалних сертификата, израду студије (заједно са институцијама Владе САД) о изводљивости језера Газиводе/Ујма о подели енергије и воде, о надзору путника у ваздушном саобраћају и међусобној размени информација, о заштити верских објеката и спровођењу судских одлука које се односе на Српску православну цркву и др.40.

Србија и Косово су се, поред тога, сложили да спроведу једногодишњи мораторијум у односу на своје активности на међународном плану у вези косовског питања. Србија да обустави „кампању повлачења независности и да се уздржи од тога да званично или незванично захтева од било које земље или међународне организације да не призна Косово (Приштину) као независно“41, док је обавеза Косова је да обустави „захтевање чланства у међународним организацијама“. 42

Да оснивање Међународне развојне финансијске корпорације (ДФЦ), поред развојне димензије, има и друге циљеве, потврдили су сарадници ове корпорације. Поред улагања у инфраструктурне и друге пројекте и јачања америчког утицаја у Србији и региону, ДФЦ има за циљ, према речима Џ. Сејлора, сарадника корпорације, да се надмеће са кинеском страном и да „доскочи Кини“

39 Наведено према: „Београд и Приштина потписали економске споразуме са САД - Шта пише у документима“, Субота 5. септембар 2020, стр. 6.

40 Исто, стр. 6.

41 Исто, стр. 6.

42 Исто, стр. 6. 
на Балкану. 43 Извршни директор ДФЦ-а, А. Боулер је потврдио ове намере уз констатацију да кинеска улагања слабе суверенитет држава Балкана, да је „кинески приступ нека врста неоколонијализма“ и да је посао корпорације да инвестира у земље Западног Балкана како би се ојачао „њихов суверенитет“.44

Две тачке споразума које поред Београда и Приштине имају далеко ширу димензију и указују на намере Сједињених Америчких Држава да смање утицај Русије и Кине на Балкану, односе се на снабдевање енергијом и употребу 5Г опреме. У вези енергије стране су се сагласиле да ће „диверсификовати њихове изворе снабдевања енергијом“. У погледу 5Г опреме, преузета је обавеза да се у својим мрежама мобилне телефоније забрани употреба 5Г опреме „коју испоручује непроверен продавац“, а ако је та опрема већ присутна, да је треба уклонити 45 .

Одредба која се односи на снабдевање енергијом се без икакве сумње (иако то није поменуто) односи на намеру САД да се умање и обуставе испоруке гаса из Руске Федерације у Србију, али и у друге балканске државе. Русија снабдева гасом велики број европских држава 46 , међу којима и државе са простора Балкана. За САД испорука руског гаса некој држави представља знак утицаја Русије. Исти став дели и НАТО. То потврђује став Политичког одбора Парламентарне скупштине НАТО-а, односно пододбора за НАТО партнерство, који у свом нацрту Извештаја о безбедности на Западном Балкану, из септембра 2018. године, констатује да је Русија доминантна у извозу гаса у Србију, Северну Македонију и Босну и Херцеговину (остале државе Балкана набављају мање количине руског гаса) и да ту позицију користи као „један од својих примарних геополитичких средстава за утицај - енергетску политику - широм региона“47. САД су, заједно са Бриселом, биле против изградње гасовода „Јужни ток“, чији је један од кракова требао да обезбеди снабдевање Србије руским гасом (из Русије, преко Бугарске, до Србије и даље према Аустрији) 48 , што је имало за последицу да овај пројекат буде

43 Наведено према: Може ли амерички ДФЦ да доскочи кинеској иницијативи „Појас и пут“, Политика, Петак, 2. октобар 2020, стр. 11.

44 Наведено према: Боулер: Кинески приступ је неоколонијалистички, Политика, Петак, 2. октобар 2020, стр. 11.

45 Исто, стр. 6

46 Количина гаса коју Руска Федерација испоручује европским државама представља већ друже време 35-40\% потреба земаља Европе за гасом из Русије и то највише за државе чланице ЕУ (око 200,6 милијарди м³ гаса). Међу државама које увозе руски гас су државе са простора Балкана. Видети детаљније: Обрадовић Ж., Станојевић П., Јефтић З., Природни гас као предмет геополитичких интереса држава, Српска политичка мисао број 3/2020, Београд 2020. год., (у штампи)

47 Наведено према: Raynell Andreychuk.2018., Securityin The VESTERN BALKANS“, SubSommitteeon NATO Partnerships (PCNP), www.nato-pa.int 178 PCNP 18E Rev. 1 fin/Original: English/21.septembar 2018,p.7.

48 Председник Бугарске Бојко Борисов је говорио о огромном притиску Западне Европе и САД да се „Јужни ток“ заустави. Видети детаљније: Обрадовић Ж., Станојевић П., Јефтић 3., Наведено дело: Исто, стр. 12-14. 
заустављен 2014. године. САД су против изградње и гасовода „Турски ток“, којим се гас транспортује из Русије до Турске, а затим једним краком гасовода до Бугарске, Србије, Мађарске и других европских држава (изградња овог крака гасовода још увек није у потпуности завршена - прим. аут.). Колико су САД озбиљне у намери да зауставе „Турски ток“ показује усвајање Закона о војном буџету САД за 2020. годину, којим се уводе санкције компанијама које учествују у изградњи овог гасовода. 49

С обзиром на висок ниво односа Србије и Русије (стратешко партнерство) и значај руског гаса за потребе развоја Србије, сигурно је да Србија неће прекинути снабдевање гасом из Русије. Остаје ипак да се види шта за САД конкретно значи одредба „диверсификација снабдевања енергијом“, какви ће бити захтеви према Србији и њен одговор.

Одредбе споразума које се односе на коришћење 5Г опреме, наравно, представљају део кампање САД против кинеске телекомуникационе компаније Хуавеј, који трају већ две године, у намери да се обезбеди надмоћ у области телекомуникација на глобалном нивоу. Да ова одредба неће утицати на сарадњу између Кине и Србије у области телекомуникација потврдио је председник Србије оценом да „у Вашингтонском споразуму није наведено да Србија не може да користи кинеску опрему за 5Г мрежу, већ да не може да користи опрему за 5Г мрежу која није проверена. ${ }^{50}$ Председник је потврдио да Србија има намеру да и даље развија сарадњу са Кином „као поузданим партнером у свим областима, укључујући и област телекомуникација“.51

\section{ПРИСУСТВО КИНЕ И РУСИЈЕ НА БАЛКАНУ}

На Балкану, поред традиционално присутних интереса европских држава, исказаних у савремено доба кроз политику Европске уније, као и Руске Федерације и САД-а, у последњој деценији у балканска питања укључила се још једна глобална сила - Народна Република Кина. Постојеће билатералне односе са балканским државама Кина је унапредила кроз Процес сарадње са земљама централне и Источне Европе. Унутар овог процеса, међу 17 држава, налази се десет балканских држава, чланица ЕУ и кандидата за чланство у ЕУ. Сарадња Кине са балканским државама је превасходно економског карактера, док је политичка димензија међудржавних односа, осим у случају Србије, објективно у другом плану. Сарадња Кине са балканским државама је важан део Процеса 17+1. Од осам до сада одржаних самита Кине са земљама Процеса сарадње 17+1, који се одржавају на нивоу председника влада̂ држава чланица, четири су одржана у

\footnotetext{
49 Видети детаљније: Исто, стр. 15-18.

50 Наведено према: Коме смета кинеска опрема, Политика, субота 12. септембар 2020, стр. 11.

51 Наведено према: Србија ће наставити да развија сарадњу с Кином, Политика, 12. септембар 2020., стр. .5
} 
балканским државама: у Букурешту (2013), Београду (2014), Софији (2018) и Дубровнику (2019). Поред тога, у државама Балкана, у протеклим годинама, на нивоу министара̂, одржани су бројни састанци о сарадњи у различитим областима: науци, образовању, трговини, пољопривреди, туризму, култури и др. Реализација пројеката у Процес сарадње 17+1 подразумева оснивање различитих асоцијација (центара) у државама чланицама, наравно и државама на Балкану. Тако је у Румунији планирано оснивање Центра за енергетику, у Словенији Центра за шумарство, у Србији Центра за сарадњу у области саобраћаја и инфраструктуре, у Бугарској Центра за високошколско образовање (које има ротирајуће председавање), али и Центра за сарадњу у области пољопривреде и др. Балканске државе су потписале више споразума о сарадњи са НР Кином у различитим областима, као нпр. Словенија у области шумарства, Албанија о размени валута са НР Кином, Румунија о сарадњи у образовању, Македонија, Румунија и Словенија споразум о надзору квалитета, Србија и Македонија споразум о контроли квалитета и др. ${ }^{52}$

Посебан квалитет и суштина сарадње балканских држава са НР Кином унутар Процеса сарадње 17+1 јесте реализација бројних пројеката, нарочито у области инфраструктуре и енергетике. Највећи број уговора закључених са Кином су билатералног карактера, али постоји и одређени број уговора регионалног карактера. Међу пројектима који су потписани или је започета њихова реализација својим значајем се истиче пројекат реконструкције и изградње брзе пруге Београд - Будимпешта (за путнички и транспортни саобраћај), чија је реализација у току. Кинеска компанија у Црној Гори изводе радове на изградњи аутопута који би повезао поморски део Црне Горе са Србијом. Кинеске компаније изводе радове на више деоница овог аутопута у Србији, а договорена је изградња дела аутопута кроз Србију до границе са Црном Гором. Босна и Херцеговина је у сарадњи са НР Кином завршила изградњу термоелектране у Станарима. У Хрватској, кинеска компанија гради Пељешки мост. И у осталим балканским државама Кина има пројекте који су потписани или је започета њихова реализација. Кинеске компаније су купиле више предузећа у балканским државама. Примера ради, железару у Смедереву купио је кинески „Hestil“. Луку у Пиреју (Грчка) постала је власништво компаније „Сosco“. У Словенији, познату фабрику беле опреме „Горење“ купила је компанија „Hisense“ и др. На нивоу билатералних односа, међу балканским државама највиши ниво односа свеобухватно стратешко партнерство са Кином - има Србија. Стратешки

52 Сви подаци наведени према: Obradović prof. dr Žarko, „Pojas i put“: Balkanska perspektiva (političko-bezbednosni aspekti), Zbornik radova: NOVI PUT SVILE: BALKANSKA PERSPEKTIVA (političko-bezbednosni aspekti), Fakultet bezbednosti - Univerzitet u Beogradu, Beograd 2016. god., str. 83-97; Obradović Žarko, „Pojas i put“ na Balkanu i Srbiji (izazovi saradnje), Zbornik radova: NOVI SPUT SVILE: EVROPSKA PERSPEKTIVA (Bezbednosni izazovi/rizici unutar inicijative 16+1), Univerzitet u Beogradu - Fakultet bezbednsti, Beograd 2018. god., str. 157-177. 
партнери Кине на Балкану су још и Грчка и Бугарска. Кина има развијене међудржавне односе и са осталим балканским државама.

По нивоу међудржавних односа, броју пројеката који су потписани, реализовани или је започета њихова изградња, по величини улагања у домаћу привреду од стране кинеских компанија, међу балканским државама, далеко испред свих осталих налази се Србија. Две државе, НР Кина и Република Србија, су 2009. године успоставиле „стратешко партнерство“, које је 2013. године „проширено“, а од јуна 2016. године подигнуто на још виши ниво „свеобухватног стратешког партнерства“. Тон одличним међудржавним односима, који се карактеришу као „челично пријатељство“, дају председници две државе: Си Ђинпинг и Александар Вучић, честим контактима и успостављеним личним односом. Кина и Србија су реализовале бројне заједничке пројекте у Србији. Између осталих, кинеске компаније су направиле мост преко Дунава, започета је изградња брзе пруге Београд - Будимпешта (у делу кроз Србију), кинеске компаније граде делове аутопута Београд - Јужни Јадран, који треба да повеже Србију и Црну Гору, прави се обилазница око Београда, завршена је ревитализација блока 2 Термоелектране у Костолцу и започета изградња новог блока 3, извршена ревитализација површинског копа Дрмно и др. Поред железаре у Смедереву, коју је купио „Hestil“, рударско-топионичарски басен у Бору постао је део компаније „Ziđin“. У Зрењанину, компанија „Šandoug Linglong“ је основала фабрику гума. И друге кинеске компаније су започеле своје послове у градовима Србије. За економију државе кинеска улагања значе отварање нових радних места или очување постојећих, нове инвестиције, нову кинеску технологију, заједнички наступ на тржиштима трећих земаља. Србија и Кина имају веома развијену сарадњу и у војној области.

У погледу односа према косовском питању Кина је увек подржавала Србију. Она је била против бомбардовања СР Југославије 1999. године и сада сматра да се мора поштовати суверенитет и територијални интегритет Републике Србије, а да се „питање Косова и Метохије мора решавати у складу са Повељом ОУН, поштовањем Резолуције СБ 1244 и да путем дијалога и преговора треба наћи прихватљиво решење“53. Наравно, она није признала једнострано проглашену независност Косова. У УН (Савету безбедности), поводом расправа о ситуацији на КиМ, Кина је критиковала рад мисијаิ УН и оцене УНМИКА-а. Она подржава разговоре Београда и Приштине под окриљем ЕУ и тражи од Приштине да примени потписане обавезе, поготову у погледу формирања Заједнице српских општина. У равни државних односа, Кина пружа подршку Србији у међународним организацијама, посебно у Уједињеним нацијама, као стални члан Савета безбедности, у борби за очување територијалног интегритета и спречавању афирмације тзв. независног

53 Видети детаљније: „Заједничка изјава Републике Србије и Народне Републике Кине о успостављању свеобухватног стратешког партнерства“, Београд 18. јун 2016.

Internet, www.fmprc.gov.cn

$01 / 08 / 2016$. 
Косова. У време пандемије вируса ковид 19 Србија је од НР Кине добила велике количине медицинске опреме и апарата. Поред тога, кинески лекари су дошли у Србију како би својим знањем и искуством помогли да се заустави ширење овог опасног вируса.

Русија је дуго присутна на простору Балкана и сарађује са свим балканским државама. Ти међусобни односи (балканских држава са Русијом) су током времена имали своје успоне и падове, у зависности од дешавања на глобалном плану, али и променама у спољнополитичкој оријентацији балканских држава. У последње две деценије, међу државама Балкана, Србија има најразвијеније односе са Руском федерацијом и њен је најзначајнији партнер на овом простору. Између Русије и Србије 2013. године потписана је Декларација о стратешком партнерству. Сарадња постоји на свим пољима: политичком, економском, војном, културном и др. У области енергетике, Русија је главни снабдевач Србије природним гасом 54 , што САД настоје да умање, односно, прекину. Сусрети представника двеју држава на највишем нивоу: председника, влада и парламената̂ су веома чести. Између две земље постоји стална консултација око учешћа у међународним организацијама (Уједињеним нацијама, ОЕБС-у, УНЕСКО-у, Интерпол-у, и др). Русија подржава ставове Србије око начина решавања косовског питања. Русија је, такође, била против бомбардовања СР Југославије 1999. године, као што је била и против тзв. независности Косова. У Уједињеним нацијама, као стална чланица Савета безбедности, Русија тражи поштовање Резолуције СБ УН 1244. Више пута је критиковала рад цивилне и војне мије УН на Косову. Русија подржава преговоре Београда и Приштине под окриљем ЕУ, али је више пута критиковала ЕУ зато што се не спроводи Бриселски споразум. Она сматра да ЕУ „треба да непристрасно и ефикасно испуњава своје обавезе и да настоји да се остваре раније постигнути договори, које косовски Албанци отворено игноришу. Прворазредни значај имају формирање Заједнице српских општина и решавање питања везаних за избеглице и интерно расељена лица“.55 Русија такође сматра да решење дијалога између Београда и Приштине може да да̂ „резултате само уз стриктно поштовање међународног права, законитих интереса и забринутости косовских Срба“56, и да Приштина и Београд треба да постигну чврсто, одрживо и обострано прихватљиво решење.

Привредна сарадња између две државе је у порасту. Обим робне размене је 2019. године износио више од две и по милијарде долара. Русија и Србија заједнички

\footnotetext{
54 Видети детаљније: Обрадовић Ж., Станојевић П., Јефтић 3., Природни гас као предмет геополитичких интереса држава, Српска политичка мисао 3/2020, Београд, 2020 (у штампи)

55 Наведено према: Решење уз договор са Србима на КиМ: Ауторски текст руског амбасадора Александра Боцана - Харченка за Напредак, https://www.novosti.rs/c/vesti/politika/927196/resenje-dogovor-srbima-kim-autorskitekst-ruskog-ambasadora-aleksandra-bocana-harcenka-napredak 19.10.2020, Приступљено 20.10.2020

56 Наведено према: Исто,
} 
реализују више пројеката у области инфраструктуре и енергетике. Доказ добрих односа између две државе потврђује оснивање и рад руско-српског хуманитарног центра у Нишу, који реагује у ванредним ситуацијама, у отклањању последица елементарних непогода (гашење пожара из ваздуха, санирање последица поплава и сл). Предвиђена је могућност реаговања Центра у Нишу и на ванредне ситуације и у другим државама Балкана. ${ }^{57}$

Између Србије и Русије постоји веома јака војно-техничка сарадња. Србија од Русије набавља, куповином или у облику донација руске стране, различите врсте наоружања, било да је реч о новом наоружању или резервним деловима за оружје које је део војног арсенала Војске Србије. Тако су део наоружања српске војске постали и „панцир“ - савремени артиљеријско ракетни систем противваздушне одбране, ловачки авиони „миг 29“, хеликоптери Ми-35, транспортни хеликоптери Ми-17, тенкови Т-72, борбена возила БРДМ-2МС и др.58 Министарство одбране Руске Федерације планира да отвори канцеларију при Министарству одбране Србије, са циљем „пружања подршке и бржег решавања питања у вези с војнотехничком помоћи као и војне сарадње“59. Војска Србије учествује у заједничким војним вежбама са војском Руске Федерације. Оваква садржајна војна сарадња између Србије и Русије изазива бројна сумњичења и критике, како од западних земаља, тако и међу земљама у региону. ${ }^{60}$ На критике такође наилази и учешће војске Србије у заједничким војним вежбама са војском Русије. Тако је због великог притиска Европске уније на Србију отказано учешће Војске Србије на заједничкој војној вежби са Русијом и Белорусијом средином септембра 2020. године. Влада Републике Србије је донела одлуку да се у наредних шест месеци замрзне учешће Војске Србије на свим војним вежбама и са свим партнерима, како би се сачувала војна неутралност. ${ }^{61}$

Србија никада не гласа против Русије у међународним организацијама, нити жели да се придружи земљама ЕУ у увођењу санкција Русији. Такав став Србије према Русији предмет је бројних критика западних земаља које сматрају да Србија, као кандидат за чланство у ЕУ, мора да усклади своју спољну политику са политиком Европске уније и да следи ЕУ у политичким одлукама и предузетим мерама против Русије. Председник Србије више пута је поновио да Србије упркос

57 Видети детаљније: руско-српски хуманитарни центар - Амбасада Руске Федерације у Републици Србији, https://ambasadarusije.rs/sr/rusko-srpski-humanitarni-centar, Приступљено 20.10.2020.

58 Наведено према: Москва послала генерала да буде војни аташе у Србији, Политика, среда 21. октобар 2020, стр. 6

59 Наведено према: Министарство одбране Русије имаће представништво у Београду, Политика, среда 21. октобар 2020, стр. 1,6; Зашто је Лавров изабрао Београд уместо Загреба, Политика, субота 24. октобар 2020,, стр. 6

60 Видети детаљније: Зашто региону смета модернизација српске војске, Политика, уторак 20. октобар 2020

61 Наведено према: Bez Srbije na vojnoj vežbi u Belurusiji, 9. septembar 2020, https://www. Slobodnaevropa.org/a/bez-srbije.na-vojnoj-Ve\%C5\%Bebi-u-belorusiji-/30829599.html, Приступљено 11.10.2020 
притисцима, „никада неће увести санкције Русији..“ и да неће „покварити односе са Русијом“.62

Деловање Европске уније и САД-а према другим великим силама, пре свега Руској Федерацији и НР Кини, има за циљ да смањи њихов утицај на простору Балкана. Од балканских држава се очекује, да следе одлуке ЕУ и САД-а, како чланице ЕУ, тако и кандидати за чланство у ЕУ63, чак и кад то не одговара њиховим интересима.

Индикативно је да ЕУ константно понавља став о обавези Србије, као државе кандидата, да усагласи своју спољну политику са политиком ЕУ, тј. придружи се санкцијама против Русије, иако у преговарачком поглављу 31, под називом „Спољна, безбедносна и одбрамбена политика“, стоји да се од „држава кандидата очекује да се у процесу преговора усклади декларацијама и мерама које је усвојила у претходном периоду ЕУ“64. Ако се зна да је процес преговора о приступању Србије са Европском унијом започет 21. јануара 2014. године, и да је у протеклих готово седам година отворено 18 од укупно 35 поглавља, а привремено су затворена два поглавља, лако је закључити да ће преговори о осталим поглављима (и тиме испуњавању услова за стицање статуса члана ЕУ) трајати јако дуго. Ако се такође зна да је поглавље 35, под називом „Остала питања: Нормализација односа Србије и Косова““, за Србију најтеже, јер не жели да призна тзв. независност Косова, да ће у оквиру овог поглавља разматрати „питање нормализације односа“, да „договори постигнути у току преговора у појединачним поглављима не смеју се сматрати коначним док не буду постигнут свеукупан договор за сва поглавља“ и да у случају да заостаје „напредак у нормализацији односа са Косовом“, а да је „разлог томе пропуст Србије да поступи у доброј мери, нарочито када је реч о примени споразума који су постигнути између Србије и Косова“, и да ће Комисија ЕУ, самостално или на захтев једне трећине држава чланица предложити да се поглавља за преговоре не отварају, односно започета поглавља затворе65, још јасније је колико преговори о приступању могу бити не само дуги, него и кориштени за притисак на Србију да призна независност тзв. државе Косово.

62 Наведено према: Нећемо уводити санкције Русији, Политика, четвртак, 15. октобар 2020, стр. 4

63 Од балканских држава које су чланице ЕУ се, сасвим логично, очекује да све одлуке ЕУ поштују и примене.

64 Дијапазон рестриктивних мера које примењује ЕУ креће се у распону од дипломатских до економских мера. Видети детаљније: „О Poglavlju 31 - Spoljna, bezbednosna i odbrambena politika“ http://eukonvent.org/o-poglavlju-31-spoljna-bezbednosna-iodbrambena-politika/, Приступљено 15.10.2020.

65 Наведено према: „Конференција о приступању Европске уније - Србија: Приступни документ: ЗАЈЕДНИЧКА ПОЗИЦИЈА ЕВРОПСКЕ УНИЈЕ, ПогЛавље 35 - Остала питања, Ставка 1. Нормализација односа Србије и Косова*, Ministarstvo za evropske integracije, Republika Srbija, https://www.mei.gov.rs/srl/dokumenta/en-dokumenta/pristini-pregovorisa-eu-pregovaračke-pozicije/pregovaračke-pozicije-za-poglavlje-35, 15.10.2020. 
Повезаност решавања односа Београда и Приштине, односно решавање Поглавља 35, о нормализацији односа између Србије и Косова, потврдио је и председник Републике Србије после разговора са специјалним изаслаником ЕУ за дијалог између Београда и Приштине, констатацијом да је „пут ка ЕУ условљен тиме какве ћемо односе направити с Приштином“.66

И Сједињене Америчке Државе врше притисак на балканске државе да одустану од сарадње са Кином и да прекину већ започете заједничке пројекте. Тако је због огромног америчког притиска на Албанију ова земља одбила да прода луку Драч кинеским компанијама67. У Румунији, због притиска САД и ЕУ, румунска влада је упутила захтев компанији Нуклеар електрика (а Влада је била власних 80\% вредности ове компаније) да прекине преговоре са кинеским партнером о изградњи два нова нуклеарна реактора (поред два већ постојећа). ${ }^{68 Д р ж а в н и ~ с е к р е т а р ~ С А Д ~ М . ~}$ Помпео приликом посете Хрватској, 2. октобра 2020. год. Тражио је од Хрватске да прекине сарадњу са НР Кином, уз оцену да су „Кинези дошли у Хрватску градити Пељешки мост како би узели паре“, као и да не користе телекомуникациону опрему кинеских компанија, али Хрватска није пристала на ове захтеве“.69

\section{ЗАКЉУЧАК}

Велике силе, делујући на простору Балкана, свака на свој начин, настоје да постигну посебне, а некад и заједничке циљеве. За западне земље, САД и већину чланица Европске уније, заједнички стратешки циљ је да политички и безбедносно „заокруже“ простор Балкана као део западних геополитичких интереса. То у овом тренутку значи да умање политички утицај Руске Федерације, економско присуство НР Кине и реше најважније „отворено питање“ на Балкану: косовско питање. Иако су садашње методе ЕУ и САД различите, суштина је иста:

66 Наведено према: „Тражимо пуну примену Бриселског споразума - порука председника Србије Мирославу Лајчеку после сусрета у Београду“, Политика, петак 16. октобар 2020, стр. 5.

67 Наведено према: Финансијске инјекције за политички утицај - одмеравање снага великих сила на Западном Балкану, Политика, субота 10. октобар 2020, стр. 6.

68 Нуклеарелектрика је 2015. године потписала писмо о намерама са кинеском компанијом China General Nuklear да успоставе заједничко улагање за развој, изградњу и рад два нова реактора. Основ за сарадњу на овом пројекту постављен је потписивањем споразума између Кине и Румуније о сарадњи у производњи нуклеарне енергије. Споразум је потписан током одржавања Другог самита Процеса сарадње 17+1, 2013. године у Букурешту. Наведено према: Amerika preko Rumunije zaustavila kineski Pojas i put, 10.06.2020, https:// novaekonomija.rs/vesti-iz-sveta/amerika-preko-rumunijezaustavila-kineski-pojas-i-put, Приступљено 17.10.2020; Kina ulaže u proizvodnju energetike u Rumuniji, 25.11.2013 https://www.bizlite.rs/64056-kina-ulaze-u-proizvodnjuenergetike-u-rumuniji; Приступљено 17.10.2020.

69 Видети детаљније: Хрватска одбила Помпеа, Новости, Субота, 3. октобар 2020, стр. 8:

„Siguran sam da građani Hrvatske to ne žele“, https://www.b92.net/info/vesti/index.php?yyyy=2020\&mm=10\&dd=02\&nav_category=167 \&nav_id=1741837,

Приступљено 02.10.2020. 
приморати Србију да прихвати тзв. независност Косова и тиме затворити процес подршке стварању косовске државе, највидљивије исказану кроз агресију НАТО пакта на Србију (СР Југославију) 1999. године и кроз једнострано признање тзв. независности Косова 2008. године. У остварењу овог циља присутно је ривалство између ЕУ и САД око тога ко ће и на који начин водити процес разговора између Београда и Приштине, јер се кроз то уједно и показује снага утицаја САД или ЕУ на Балкану. Унутар Европске уније, у креирању ставова (докумената) ЕУ, како према косовском питању, тако и према целом простору Балкана, доминантни су ставови СР Немачке. Директно и(ли) индиректно, Немачка је суштински утицала на садржај докумената ЕУ који су предмет преговарачког процеса Србије за стицање статуса члана ЕУ (то је најизраженије када је реч о решавању косовског питања, ком је посвећено посебно поглавље - поглавље 35, и од чијег исхода практично зависи цео преговарачки процес).

Република Србија учествује у разговорима и са САД и са ЕУ. У оба случаја настоји да кроз дијалог оствари праведно решење косовског питања, не доводећи у питање ни оријентацију да буде чланица ЕУ, ни да има добре односе са САД, Руском Федерацијом и НР Кином, нити да угрози статус војно неутралне државе.

И Руска Федерација и НР Кина су традиционални пријатељи Србије. Обе земље не признају тзв. независност Косова и подржавају Србију да се проблем Косова реши дијалогом, поштујући Резолуцију СБ 1244 и уважавајући интерес Србије. Имајући у виду чињеницу да су Русија и Кина сталне чланице Савета безбедности УН са правом вета, може се разумети колики значај има за Србију што са ове две државе има односе „стратешког партнерства“, не само приликом решавања косовског питања него и око других тема од значаја за Србију. Русија већ готово два века, са више или мање успеха, настоји да буде присутна на Балкану и утиче на решавање отворених питања. Поред одличних односа са Србијом, Русија има развијене односе и са другим балканским државама, пре свега кроз економску (енергетску) сарадњу али и са становишта позиције велике силе. НР Кина, са друге стране, тек је у последњој деценији значајно присутна на Балкану, а нарочито у Србији. Кина сарађује са свим балканским државама унутар Процеса сарадње 17+1. У сарадњи са балканским државама, Кина је реализовала (или је у току реализација) више инфраструктурних пројеката, као и у области енергетике. Међу државама Балкана, најзначајнији партнер Кине је Србија, са највећим бројем потписаних, започетих или реализованих пројеката. Сарадња са државама Балкана је део односа Кине са Европском унијом, али на стратешком плану још више део реализације великог кинеског развојног пројекта „Појас и пут“. То је и логично када се зна да је Процес сарадње 17+1 (у ком је окупљено 10 држава Балкана) део „Појаса и пута“ и налази се на западном правцу реализације овог пројекта.

Геополитичку димензију присуства Кине на простору Балкана можемо разматрати само у контексту реализације глобалне развојне иницијативе „Појас и пут“ у Европи, при чему је Балкан тек део, и то мали, овог огромног инвестиционо-развојног пројекта. За Кину су далеко важнији укупни односи са ЕУ, него са једним бројем чланица и кандидата за чланство у ЕУ. Али сарадња са балканским државама, поготову Србијом, и будући заједнички развојни пројекти, јесу добар пример свима другима да сарадња са Кином доноси бенефит државама партнерима, да унапређује сарадњу и повезаност држава, билатерално и у региону. Сарадња са Кином се на тај начин појављује као алтернатива сарадњи са ЕУ и државама чланицама. Ово је утолико значајније кад се зна да је од једанаест 
држава на Балкану само пет у чланству ЕУ, пет у статусу кандидата и шеста држава је потенцијални кандидат (БиХ), а да се ЕУ суочава са бројним унутрашњим проблемима (економске кризе у једном броју држава чланица, негативне последице пандемије вируса ковид 19, напуштања ЕУ од стране В. Британије, најављене реформе унутар ЕУ, непостојање јасних датума око будућег проширења ЕУ, тј. пријема нових чланова и др.). Све то „европску перспективу“ балканских држава чини отвореном и за неке државе (Турска) и готово немогућом. Када се томе дода и косовско питање, тј. однос ЕУ према централној држави Балкана - Србији, може се разумети ова комплексност, али и рањивост деловања ЕУ на простору Балкана. Иако „окупља“ готово све државе на Балкану, ЕУ није успела да се наметне као водећа политичка снага. Томе је допринело потпуно или неадекватно нереаговање ЕУ на потезе Албаније (најава укидања граница са тзв. државом Косово), привремених институција Косова код формирања војске, увођења такси на робу из Србије и БиХ, или упорно одбијање Приштине да примени одредбе Бриселског споразума. Таква „немоћ“ ЕУ ствара простор балканским државама да траже нове партнере за сарадњу, како економску, тако и политичку.

Јасно је да ЕУ и САД не желе „јаке“ НР Кину и Руску Федерацију на простору Балкана, и то из два разлога. Прво, јер то ремети њихове стратешке планове о утицају (контроли) целог простора Балкана. Присуство Кине и Русије представља пукотину у жељеној монолитности целог региона. Други разлог лежи у могућности да Кина и Русија (поготову Кина због свог потенцијала за улагање) за балканске државе постану алтернативни или једини партнер у будућој сарадњи, што би значило смањену моћ и утицај САД и ЕУ. Зато и једни и други, понудама за реализацију бројних пројеката, тј. кроз економска улагања настоје да што више вежу балканске државе за себе и удаље од Кине и Русије. Балканске државе су већ део одређених политичких и безбедносних интеграционих процеса (чланство у ЕУ и НАТО), што у огромној мери опредељује и домете њихове сарадње са Кином или Руском Федерацијом. Изузетак од тога је Србија у делу припадности некој војној организацији, јер је прогласила војну неутралност. Ипак будућа дешавања на глобалном нивоу, (односи између великих сила, различите безбедносне претње, економска криза и др.) унутар ЕУ и НАТО пакта, или самих држава чланица, увек остављају могућност да може доћи до промена у постојећим односима и да ће балканске државе у складу са својим интересима бирати партнере међу великим силама и садржај будуће сарадње.

\section{БИБЛИОГРАФИЈА:}

1. Obradović Žarko, Jeftić Zoran, Stanojević Petar, Global Relationsin the International Communityand Cooperation between Serbia and Chinain the Implementation of the Beltand Road Initiative, In: Liu Zuokui (ed) "The Cooperation between China and Balkan Countries under the Beltand Road Initiaive", China-CCEC Think Tank Book Series, Beijing, 2019.

2. Obradović, Žarko, „Pojas i put na Balkanu (izazovi saradnje)“, U: Vladimir Cvetković (ur.) Novi put svile: Evropska perspektiva - bezbednosni izazovi/rizici unutar Inicijative 16+1, Beograd, Fakultet bezbednosti Univerziteta u Beogradu, 2018, str. 157-177. 
3. Obradović, Žarko, „Pojas i put: Balkanska perspektiva (političko-bezbednosni aspekti)“, U: Vladimir Cvetković, Šao Binhongetal. „Novi put svile: Balkanska perspektiva - političko-bezbednosni aspekti“, Beograd: Fakultet bezbednosti Univerziteta u Beogradu, 2016, str. 83-97.

4. Obradović, Žarko, Bezbednosni izazovi i stubovi spoljne politike Srbije, Tematski zbornik radova sa međunarodne naučne konferencije "Dani Arčibalsa Rajsa", Kriminalističko-policijska akademija u Beogradu, Beograd, 2018, str. 219-233.

5. Obradović, Žarko, Strateško partnerstvo „male Srbije“ i „velike Kine“, Srpska politička misao, Institut za političke studije, broj 3/2016, Beograd, 2016, str. 121137.

6. Vujović Mišo, Masakriranje istine, Kulturni centar „Sveti Sava“ - Podgorica, Beograd 2002.

7. Ђукановић Драган, Крстић Милан, „Берлински процес - Немачка „Западнобалканска“ иницијатива“, Српска политичка мисао, год. 23. вол. 54, Београд, 2016.

8. Кривокапић Борис, Агресија НАТО-а на Југославију - сила изнад права, Чигоја штампа, Београд, 1999.

9. Обрадовић, Жарко, Балкански етнички мозаик - мањинско питање на Балкану, Чигоја штампа, Београд, 2014.

10. Обрадовић, Жарко, Станојевић Петар, Јефтић Зоран, „Природни гас као предмет геополитичких интереса држава“, Српска политичка мисао, 3/2020, Београд, 2020. (у штампи).

11. Стевановић, Обрад, Кумановски споразум, Криминалистичко-полицијска академија, Београд, 2015.

\section{GEOPOLITICAL INTERESTS OF THE GREAT POWERS IN THE BALKANS DURING THE LAST DECADE AND THE KOSOVO ISSUE}

The paper will seek to provide an answer to the question why the Balkans, in the second decade of the XXI century, has again become a subject of interest of the great powers, and what is the attitude of the great powers towards the Balkans' states. In the Balkans, in addition to the already present European countries (whose policy is increasingly expressed in modern times through the activities of the European Union), the Russian Federation and the United States, during this decade the presence of the People's Republic of China has increased (through numerous joint infrastructure projects energy, etc.). The Kosovo issue, which the Western countries claimed was over, was "re-opened" again by Serbia's activity and became the central issue of the entire region, which, in their own way, the European Union and the United States are trying to resolve. The agreement from Washington showed that the United States gives priority to economic issues instead of political ones, with the expectation that such an approach will create conditions for a political agreement between Belgrade and Priština. By appointing a special envoy for the negotiations between Belgrade and Priština, the European Union is trying to reach an agreement on the normalization of relations between the two sides through the negotiations. At the same time, both the EU and the United States, each in its own way, are striving to achieve another goal: to reduce the influence and presence of the People's Republic of China and Russia among the Balkan states.

Key words: Balkan states, great powers, European Union, Kosovo issue, geopolitical interests 